\title{
Discussion on the Mode of Art Education Resources Sharing between Universities and Primary and Secondary Schools
}

\author{
Junxia Yan \\ Huanghe Science and Technology College \\ Zhengzhou, China
}

\begin{abstract}
In order to realize the sharing of art education resources between universities and primary and secondary schools, this paper analyzes four aspects: sharing of teachers' resources, sharing of school buildings and professional hardware facilities, sharing of books and materials and joint education, and discusses the enhancement of art education in universities and primary and middle schools by optimizing the allocation of resources and improving the rules and regulations.
\end{abstract}

Keywords-university; art education; resource sharing

\section{INTRODUCTION}

At the beginning of the 20th century, under the influence of the western aesthetic education idea, the modern art education thought of our country is gradually forming in combination with its own characteristics. As our basic education is improved continuously and our quality education is advanced fully, aesthetic education has become an important part of our educational policy, but art education is the basic way to implement aesthetic education in colleges and schools.

Today, the education policy is implemented fully and the quality education is fulfilled greatly, but what is the purpose of art education? Thomas Monroe, the famous contemporary American esthetician, divided artistic education into four different types: "One is to emphasize the technical training in artistic practice, which aims at cultivating the artist; another is to emphasize the evaluation of art appreciation and comprehension; the third is to emphasize the systemic education of art history; the last is to stress on the teaching methods of art, which mainly aims at training art teachers." ${ }^{1}$ In recent years, the art education of primary and secondary schools has developed rapidly in China, but art education is still the weak link in our school education from the overall development of basic education in China. Art education has lack of course setting, single form of activity, shortage of teachers and deficiency of resources, which have restricted the development of art education in primary and secondary schools in different degrees and hindered the balanced development of basic education and full promotion of quality education. If we only increase the investment of the government, the solution of problems in art education

1 [US] Thomas Monroe. Aesthetics towards Science [M]. Beijing: China Federation of Literary and Art Circles Publishing Company, 1985.

Fund Project: the stage results of Humanities and Social Sciences Research Youth Project "Study on the Landscape Design Symbol of Henan Academy in Ming and Qing Dynasties" of Henan Provincial Department of Education in 2016, project number: 2016-QN-043. resources has a low effect and the aesthetic education of primary and secondary schools can not be fundamentally improved. Based on this, "to achieve the mode exploration of art education resource sharing in colleges and primary and secondary schools", we will optimize the allocation of resources, improve the system and other means to enhance the level of art education in primary and secondary schools.

\section{The PRESENT SituAtion AND PURPOSE OF ART EDUCATION IN CHINA}

At present, the goal of art education in China is mainly the first two listed by Thomas Monroe, namely, one is to make professional art training for cultivating artists, and training their employability in the art industry, for example the colleges and universities set up art design, drama, screen and video, art performance, music, dance, and other majors; another is to make a universal education of it together with moral education, intellectual education and physical education in the field of aesthetic education in the modern educational structure, and take art education as one of the main ways of practice and implementation of aesthetic education, for example, the primary and secondary schools and art training classes carry out the course of art and musical instruments and other related training courses, and colleges and universities carry out art appreciation, film and television appreciation and other public elective courses. The development of art education can not only improve the students' aesthetic and humanistic qualities, but also promote the cultural heritage and enhance the healthy growth of students. Art education is based on school education and is combined with social education and family education in China. However, there are some problems in our current art education, such as the uneven development of art education in various regions, the insufficient use of art education resources and the imperfect system of art education. Taking the art design as an example, from the aspect of teachers, colleges and universities are provided with a large number of teachers with a high degree (master's degree or above), middle and senior professional titles (lecturers, associate professors and professors), with a reasonable teacher arrangement structure, while in the primary and secondary schools, art teachers generally have a relatively low education background and academic title, so there is a large gap of art education level between the compulsory education and higher education; from 
the aspect of hardware facilities: the students of art and design in colleges and universities can enjoy a professional studio, drawing room, computer-aided design room, etc., while the students in most of our primary and secondary schools have only palette, painting materials, painting props for their art education, with lack of more professional facilities. In addition, there are also such problems in dance, music and other orientations of art education.

As a unique and scarce educational resource, art urgently needs some innovative reforms for promoting the overall level of art education in China. In order to solve the current problems of art education in China, it is an innovative measure to achieve the "resource sharing" in the art education between colleges and primary and secondary schools, which will solve the dilemma of art education substantially.

\section{THE SCOPE AND FUNCTION OF ART EDUCATION RESOURCE SHARING}

Art resources sharing is to commonly use the teachers, laboratory equipment, books and other resources of various arts education phase (from early childhood education to higher education), without the boundary, and a unified distribution will be made according to the needs of different schools for the resources, all schools have the same use right. It is a cooperative and sharing development mode of mutual benefit and educational radiation.

\section{A. Reduce the Cost of Education, to Avoid Waste of Resources}

At present, China's higher education institutions have a relatively mature development of art education curriculum, more complete teachers and hardware resources. In the process of development, many science and engineering-oriented schools emphasize the study depth of various majors, so art education, as a public elective course, has a serious waste of resources and a low utilization of educational resources. The allocation and distribution of art education resources in colleges and universities is far superior to primary and secondary schools.

This largely causes primary and secondary schools have a long primary stage of art education, and makes the gap bigger and bigger between colleges and primary and secondary schools. If we only depend on the investment of the government in education to improve the art education resources of primary and secondary schools, it will be very slow. To solve this problem properly, we should improve the allocation of resources and the use of mechanisms. We can make a plan of the whole classes of higher education institutions and the surrounding primary and secondary schools, making the arts education classes of primary and secondary schools can be carried out in colleges and universities, and even can taught by the teachers of universities, while making the libraries of reading rooms of universities open to the primary and secondary schools. So we will make full use of art education resources of universities and colleges, greatly reduce the pressure of the supply of art education resources in primary and secondary schools, and effectively improve the teaching of art education in primary and secondary schools.

\section{B. Provide Further and Wide Cooperation Opportunities for the Teachers, and Promote the Professional Development of Teachers}

In our country, there is little opportunity for cooperation between the teachers of higher schools and that of primary and secondary schools. As an important aspect of art education resource sharing, the teachers sharing between the higher schools and the primary and secondary schools should be achieved. The teachers of art in universities who have higher level of teaching and professional skills can be appropriately arranged to offer the popularization course of arts education in some primary and secondary schools. Through this mode, the teachers of universities and primary and secondary schools will have more opportunities to exchange and learn, commonly undertaking scientific research projects, exploring teaching methods, enhancing professional level of communication and learning.

\section{Improve the Quality of Arts Education in Primary and Secondary Schools}

The art education of primary and secondary schools mainly includes art and music courses. The art education of primary and secondary schools in large cities can be generally provided with professional teachers with solid art foundation and skills, while most of the teachers of art education in small and medium-sized cities and rural areas are part-time although they have the specialty of art education or have certain artistic foundation. Generally, part-time art teachers have less communication with students, and they will return to the fixed work after-school and hardly answer the problems of students about the music and art homework in the spare time. Therefore, if the teaching of art education relies on part-time teachers, quality is difficult to guarantee. In this case, the art teachers be shared between the colleges and the primary and secondary schools, so that the professional teachers of colleges and universities who have deep artistic accomplishments may offer instruction in the primary and secondary schools through many forms, such as trans-school teaching, teaching support, tourtype teaching, flow instruction, appointed contact, targeted tutorship, ${ }^{2}$ so as to solve the problems of primary and secondary schools about weak art education teacher force and low teaching.

\section{THE MOdE OF ART EDUCATION RESOURCES SHARING BETWEEN UNIVERSITIES AND PRIMARY AND SECONDARY SCHOOLS}

According to the current situation of art education in China we will explore a possible mode of art education resources sharing between universities and primary and secondary schools from the following aspects.

\footnotetext{
2 Advice of the Ministry of Education on the Further Advancement of Primary and Secondary Education in Art Education. YTJ[2008] No. 8 http://www.gov.cn/gongbao/content/2009/content_1265992.htm, 2008.9
} 


\section{A. Teacher Resource Sharing}

The teacher resource sharing mode is divided into three categories: instruction, lectures and training. the unified governmental coordination is made for the art teachers of colleges and universities, planning the time out of their duty class for offering instruction in the primary and secondary schools; the government organizes teachers of colleges and universities to launch lectures of a series of art works appreciation and music appreciation and other aspects, to regularly popularize the knowledge of art for students of primary and secondary schools in different areas, improving students' aesthetic ability; some teacher trainings are organized by the government and undertaken by colleges and universities. Train the art teachers of all provincial and municipal primary and secondary schools to become national, provincial and other level academic leaders and key teachers, by which improve the teaching level and professional and technical level of teachers and promote the development of art education in primary and secondary school.

\section{B. Sharing of School Buildings and Professional Hardware Facilities}

Colleges and universities have a large scale of school buildings, equipped with more professional and complete hardware facilities, and the art course and music courses course of primary and secondary schools can be taught by use of the hardware facilities of these colleges and universities, so as to make the curriculum richer. For example, take use of professional piano room of universities for music course to transfer the traditional singing class of primary and secondary schools into piano skills training. These will basically change the class form of art education in primary and secondary schools and enrich student's art activities.

\section{Books and Documents}

In China, the universities have the exclusive right of their books and documents, which greatly limits the scope of the book users. Additionally, the same books may be collected by each school with a certain number, resulting in serious book repetition. If the libraries of both universities and primary and secondary schools are open to each other, we will save educational fun and students can expand their reading range.

\section{Joint Education}

According to the geographical location and administrative division, we can make a One-to-One or One-to-Two combination between universities and primary and secondary schools, namely the cooperation between one university and one or two primary and secondary schools, and use the common teachers and software and hardware facilities to complete the art education of students in universities and primary and secondary schools, so that universities and primary and secondary schools all can play to their respective advantages of resources, and through a overall classes arrangement, to achieve art education resources sharing and educational benefits, thereby enhancing the art education level of students.

\section{CONCLUSION}

It is a long-term process to realize the resource sharing of arts education between universities and primary and secondary schools. On the one hand, the government should introduce some planning measures and encouragement policies as guidance, on the other hand, a long-term cooperation is necessary between universities and primary and secondary schools. The mode of resource sharing is the trend of art education development in China, and it plays an essential role in promoting the level of art education.

\section{REFERENCES}

[1] [US] Thomas Monroe. Aesthetics towards Science [M]. Beijing: China Federation of Literary and Art Circles Publishing Company, 1985.

[2] Advice of the Ministry of Education on the Further Advancement of Primary and Secondary Education in Art Education. YTJ[2008] No. 8 http://www.gov.cn/gongbao/content/2009/content_1265992.htm, 2008.9

[3] Liu Zhihong. Study on Art Education Resource Sharing of University City - A Case Study of Xianlin University Town in Nanjing [J] .Journal of Culture and Education, 2012 (2)

[4] Zhang Xiaoli. Study on Cooperative System and Mechanism between Universities and Primary and Secondary Schools in the United States taking professional development schools as the center [D]. Northeast Normal University, doctoral dissertation, 2013.6

[5] Tu Xiaoyan. Investigation on current art teaching resources sharing of secondary schools in Zhoukou area under the new curriculum reform and its countermeasures [D]. Henan Normal University. master's thesis, 2013.4 